This article was published in Ethnicities through OnlineFirst on July $12^{\text {th }} 2016$, and this is the version that should be cited. The final version can be found at: http://etn.sagepub.com/content/early/2016/07/12/1468796816656674.full.pdf+html

The DOI is $10.1177 / 1468796816656674$.

\title{
Are British Muslims alienated from mainstream politics by Islamophobia and
}

\section{British foreign policy?}

Nicole Martin, University of Essex

\begin{abstract}
This paper uses the 2010 Ethnic Minority British Election Study to look at the political attitudes of Muslims in Britain. It tests the relationship between political alienation and political participation on the one hand, and Islamophobia and disapproval of British military involvement in Afghanistan on the other. The principal findings are that perceptions of Islamophobia are linked to greater political alienation, to a greater likelihood of non-electoral participation and to a lower likelihood of voting among Muslims. Likewise, disapproval of the war in Afghanistan is associated with greater political alienation and a greater likelihood of some types of nonelectoral participation. There is strong evidence that British Muslims are more likely to interpret discrimination they experience as motivated by their religion, and that they perceive more prejudice at the group level. These findings have two theoretical implications. Firstly, they support the theory that non-electoral participation is motivated by dissatisfaction with the party political system. Secondly, they suggest that perceptions of sociotropic discrimination (for minorities) and a rare salient political issue in which all parties are in opposition to most voters can lead to negative affect towards the political system and stimulate non-electoral participation at the expense of voting.
\end{abstract}

Keywords: Islamophobia, Muslims, Afghanistan war, integration, discrimination

\section{Introduction}

Muslims in Britain can find themselves in a precarious space, politically and socially. Anti-Muslim sentiment has replaced the racial epithets of the British National Party, and is echoed in the wider phenomenon where Muslims are implicitly or explicitly singled out as the focus point for concerns about migration and multiculturalism. Moreover, the UK has been involved in two high profile wars in Muslim countries since 2001. These wars have been unpopular among the rest of the country too - but they were particularly unpopular among British Muslims. Muslim activists were prominent in the campaign against war in Afghanstan (Peace, 2015) and at the following general election Labour were punished in constituencies with higher proportions of Muslim voters (Curtice, Fisher, \& Steed, 2005). This paper asks 
This article was published in Ethnicities through OnlineFirst on July $12^{\text {th }} 2016$, and this is the version that should be cited. The final version can be found at:

http://etn.sagepub.com/content/early/2016/07/12/1468796816656674.full.pdf+html

The DOI is $10.1177 / 1468796816656674$.

whether Islamophobia and the unpopularity of British involvement in Afghanistan

may have contributed to political alienation and non-electoral participation among

British Muslims.

\section{Theory and context}

There are two theoretical contentions behind this paper. Firstly, discrimination can drive politically alienated attitudes because people feel that mainstream political actors and institutions do not care about their interests and have no reason to do so. Secondly, a salient political issue where mainstream parties are united in their opposition to public opinion can have the same effect. British Muslims are a good case with which to test these theoretical propositions because of the twin phenomena of Islamophobia (sociotropic discrimination) and the war in Afghanistan (a salient political issue where most of the group are opposed to the main three parties).

It is important to address this question for a number of reasons. Firstly, understanding how political behaviour and attitudes are associated with racial and religious discrimination is key to understanding immigrant political integration. It has increasing importance in European societies where ethnic and religious minorities are becoming a substantial proportion of the electorate. A key contribution of this study is to extend this debate to both non-electoral and electoral political participation, as well as attitudes. Previous work has speculated that the wars in Iraq and Afghanistan lost Labour Muslim votes in 2005, but that this effect had disappeared in the 2010 general election. If these wars are still important for some voters, it would suggest that salient policies on which major parties agree can have longer lasting impacts on attitudes towards to political system even when effects on vote choice have become negligible. Furthermore, this study contributes to generalising and testing the theory of linked 
This article was published in Ethnicities through OnlineFirst on July $12^{\text {th }} 2016$, and this is the version that should be cited. The final version can be found at:

http://etn.sagepub.com/content/early/2016/07/12/1468796816656674.full.pdf+html

The DOI is $10.1177 / 1468796816656674$.

fate in political behaviour to the British case, and to types of political action beyond

vote choice.

The most comprehensive recent study of political disaffection among ethnic minorities in Britain shows that Muslim groups are not particularly disaffected (Heath, Fisher, Rosenblatt, Sanders, \& Sobolewska, 2013). Bangladeshis and Pakistanis have noticeably higher levels of satisfaction with democracy and agreement that it is every citizen's duty to vote than the white British. There are some signs of discontent - the same authors reported slightly higher levels of protest activity among Bangladeshis and of boycotts among Pakistanis - but nothing singles out Muslim groups as particularly alienated or disengaged from mainstream British politics.

In fact, the pattern in most previous research is that South Asians tend to be the more politically active and involved of ethnic minorities in Britain. South Asians have been much more successful in achieving political gains than black Caribbean or black African groups, which would lead us to expect higher levels of cognitive engagement and satisfaction with the political process. In terms of turnout and registration, studies since the 1990s have reported either equal levels of voter turnout than whites among South Asian groups, or slightly higher (Anwar, 1990; Heath et al., 2013; Modood, 2005). Muslim voters in particular have higher levels of turnout and registration in areas with greater Muslim population density, even though these areas have lower turnout on average (Fieldhouse \& Cutts, 2008b). Heath et al. (2013) emphasize the importance of bonding social capital as resources for ethnic minority political participation, especially through ethnic and religious organizations which can be 
This article was published in Ethnicities through OnlineFirst on July $12^{\text {th }} 2016$, and this is the version that should be cited. The final version can be found at:

http://etn.sagepub.com/content/early/2016/07/12/1468796816656674.full.pdf+html

The DOI is $10.1177 / 1468796816656674$.

fostered to some extent through residential concentration. This extends to religious

identities and institutions - Jamal (2005) demonstrated that mosque attendance is associated with higher participation among New York Muslims, whilst Sobolewska,

Fisher, Heath, and Sanders (2015) estimate that regular attendance in a mosque increases the probability of participation by 7 percentage points among Muslims in the UK.

Nevertheless, given the context of Islamophobia and opposition among Muslims to the war in Afghanistan, it is reasonable to assess to what extent these twin phenomena are associated with politically alienated attitudes or distinct patterns of political participation.

Islamophobia in the United Kingdom was first observed en masse in the wake of the fatwa declared against the British Indian author of The Satanic Verses, Salman Rushdie in 1989. Following the terrorist attacks on September $11^{\text {th }} 2001$ and subsequently the 7/7 bombings in London, concerns over domestic Muslim extremism have become recurring themes in the media and in political speeches (Poynting \& Mason, 2007). Far right groups - in turn, the British National Party, English Defence League and Britain First (along with smaller groups) - have each mobilized around a hatred of Islam, appropriating liberal arguments about the emancipation of women and tolerance of homosexuality in service of intolerance towards Islam. The trend in public debate is matched when we look at empirical instances of discrimination. In a 2005 study, planning applications from mosques less likely to be approved in Birmingham than applications for gurdwaras (Sikh temples) or Christian churches (Gale, 2005). There is also evidence of a specific labour market penalty for Muslims 
This article was published in Ethnicities through OnlineFirst on July $12^{\text {th }} 2016$, and this is the version that should be cited. The final version can be found at:

http://etn.sagepub.com/content/early/2016/07/12/1468796816656674.full.pdf+html

The DOI is $10.1177 / 1468796816656674$.

from different ethnic groups, as compared to members of other minority religions

(Heath \& Martin, 2013).

British military involvement in Afghanistan and Iraq has been deeply unpopular with Muslim voters. ${ }^{\mathrm{i}}$ In the 2005 general election, Labour were punished in constituencies with larger Muslim populations, most markedly in two Birmingham constituencies where sitting Labour MPs had their majorities reduced by over 35 percent (Khan, 2005). The damage to the Labour vote among Muslims in 2005 is mostly attributed to opposition to the war in Iraq (Curtice et al., 2005; Fieldhouse, Cutts, \& Russell, 2006). The Respect Party emerged on the back of opposition to the war in Iraq, earning its first electoral victory in the May after British military action started in Iraq, and relying on Muslim voters where it did well (Peace, 2013). However, prior to this there were already voices against intervention in Afghanistan in September and October 2001, Muslim and otherwise. The anti-war movement was led by left wing and radical organizations - the nascent Stop the War Coalition, the Campaign for Nuclear Disarmament and the Green Party - but were joined by Muslim and Christian groups and individuals. Muslim prayers were held during demonstrations against intervention in Afghanistan on the $8^{\text {th }}$ October (Woolf \& Usborne, 2001), and a later protest on the $18^{\text {th }}$ November was briefly halted so that Muslim protesters could break their fast (as the protest occurred during Ramadan) (Peace, 2015). The war in Afghanistan is a rare policy in that mainstream parties have been extremely united in their opposition to public opinion. Despite a lack of mainstream opposition at the time, 70 percent of the public have been in support of bringing British troops home soon or immediately since before the 2005 general election. However, during this 
This article was published in Ethnicities through OnlineFirst on July $12^{\text {th }} 2016$, and this is the version that should be cited. The final version can be found at:

http://etn.sagepub.com/content/early/2016/07/12/1468796816656674.full.pdf+html

The DOI is $10.1177 / 1468796816656674$.

period no party was advocating withdrawal. A voter for whom opposition to

Afghanistan was the most important issue really had no one to vote for.

Political alienation can be understood as "a relatively enduring sense of estrangement from existing political institutions, values and leaders" (Citrin, Mcclosky, Shanks, \& Sniderman, 1975). Within this broad statement, it is appropriate in this case to focus on two principle dimensions. Firstly, there is dissatisfaction or withdrawal of support for key political institutions and roles - similar to Finifter's dimensions of normlessness or isolation (Finifter, 1970). Norris and colleagues argue that since at least 1970, many citizens "value democracy as an ideal yet...remain dissatisfied with the performance of their political system, and particularly the core institutions of representative governments" (Norris, 1999). This lack of support can manifest in negative evaluations of political institutions and actors- for instance, seeing parties or politicians as ineffective or corrupt.

Secondly, political powerlessness and disenfranchisement is a key dimension of political alienation (Finifter, 1970). If a person feels that none of the major parties represent their views, they may find themselves in constant disagreement with the majority of politicians. However, some citizens may be both alienated, but feel that they have political power. Gamson (1968) formalized the relationship between political trust and efficacy, arguing that low trust combined with high political efficacy is the optimum condition for participation. His expectation has been well substantiated with regards to "non-allegiant" (i.e. non-electoral or non-conventional) participation (Seligson, 1980), but not in the case of conventional electoral 
This article was published in Ethnicities through OnlineFirst on July $12^{\text {th }} 2016$, and this is the version that should be cited. The final version can be found at:

http://etn.sagepub.com/content/early/2016/07/12/1468796816656674.full.pdf+html

The DOI is $10.1177 / 1468796816656674$.

participation, where institutional participation is low among those with distrustful

attitudes, and both high and low levels of efficacy (Hooghe \& Marien, 2012).

It is easy to see how discrimination might lead someone to decide that mainstream politics are not for them. Exclusion by majority group members in social and political life may inhibit the development of a particular group identity or belonging (for instance, British identity) that promotes political participation. A rational choice story can told too; if mainstream parties have little electoral incentive to cater for ethnic minority voters, then an important supply side driver of political engagement is missing. Nationally, the incentive to court ethnic minority votes has been low until recently - and even now, only an estimated 8 percent of the electorate is non-white, although residential segregation means that ethnic minorities have electoral clout in certain areas. ${ }^{\text {ii }}$ Mainstream parties have found themselves under pressure from the extreme-right British National Party and the more respectable UK Independence Party whose policies have a strong anti-immigrant component. Neither the Conservatives nor Labour included any proposals for racial or religious equality in their 2010 manifestos; ethnic minority voters, especially Muslims, are not a priority for mainstream parties. Why trust politicians and institutions to look after one's interests if they have demonstrated that they are a low priority?

Indeed, previous research supports the idea that discrimination might lead someone to feel excluded from the wider political community. Maxwell (2009) demonstrates that perceived discrimination is associated with a lower likelihood of identifying as British among Caribbean and South Asian migrants in the UK, whilst Heath et al. (2013) show that satisfaction with democracy and trust in key political institutions is lower 
This article was published in Ethnicities through OnlineFirst on July $12^{\text {th }} 2016$, and this is the version that should be cited. The final version can be found at:

http://etn.sagepub.com/content/early/2016/07/12/1468796816656674.full.pdf+html

The DOI is $10.1177 / 1468796816656674$.

among minorities who feel that their ethnic group is disadvantaged, and that this

drives political participation. Just and Anderson (2012) show that anti-immigrant opinion climates depress participation among migrants and hinder the translation of grievances into political demands.

The link between foreign policy and political alienation is less obvious a priori.

Valence theory contends that voters respond to policy delivery. If the political system delivers satisfactory policy outcomes, citizens are more likely to engage positively with it, but if it does not the opposite will happen, and they will become alienated from the system as a whole as well as the particular party in government (Clarke, Sanders, Stewart, \& Whiteley, 2009). Foreign policy is a clear example of how this might happen - Muslims who disapprove strongly of British military involvement in Muslim countries may become less inclined to support a political system that has failed to deliver on a key policy.

This is particularly pertinent in view of the crucial role of the Labour party in integrating ethnic minorities into British electoral politics; not only did all Westminster paries support the war in Afghanistan, but it was a Labour government in charge of the military intervention. For loyal Labour Muslim voters with longstanding suspicions about the Conservative party, this meant a betrayal on a highly salient political issue without a clear alternative. British foreign policy may have had a more lasting impact on political attitudes insofar as it represented for some Muslims a permanent detachment from the Labour party and greater scepticism towards politicians in general. 
This article was published in Ethnicities through OnlineFirst on July $12^{\text {th }} 2016$, and this is the version that should be cited. The final version can be found at:

http://etn.sagepub.com/content/early/2016/07/12/1468796816656674.full.pdf+html

The DOI is $10.1177 / 1468796816656674$.

Thus far I have ignored the important difference between personal experiences of

discrimination, and feeling that one's group as a whole is discriminated against.

Dawson (1994) introduced the concept of linked fate to explain the support for the

Democrats among African Americans. To the extent that group membership means

that an individual's own fate is linked with that of the wider community, it makes

sense for individuals to substitute group utility for their own when making political

decisions. This idea has gained a large amount of support in the study of African

American electoral behaviour, and appears to be equally important in explaining the

political behaviour of Latinos in the USA (Kaufmann, 2003; Sanchez \& Masuoka,

2010; Wilson, 2012). Wilson (2012) frames this explicitly in terms of group economic voting, arguing that a key determinant of African American presidential vote choice and candidate affect was the retrospective evaluation of how the economic situation of blacks had improved, whilst personal retrospective economic evaluations were not significantly related to Democratic support.

The extent to which perceived discrimination against Muslims as a group influences political behaviour among Muslims is a way to generalise the theory of linked fate to a context outside the US, and to other political behaviour and attitudes than vote choice. The literature has stressed the importance of economic concerns; however, feeling that one's fate is linked to those who share the same ethnicity or religion also has a large social component. Being more likely to be searched by the police or experience other forms of unfair treatment from public authorities, stereotyping by teachers or verbal harassment are all more social or political experiences than economic. If we are interested in the extent to which this feeling of linked fate might influence political behaviour or attitudes, then it is necessary to see what effects 
This article was published in Ethnicities through OnlineFirst on July $12^{\text {th }} 2016$, and this is the version that should be cited. The final version can be found at:

http://etn.sagepub.com/content/early/2016/07/12/1468796816656674.full.pdf+html

The DOI is $10.1177 / 1468796816656674$.

remain once we account for individual experiences of discrimination. This study is

able to do just that.

\section{Hypotheses}

Perceptions of discrimination and group-level disadvantage are associated with a lower-likelihood of having a British identity (Maxwell, 2009), lower satisfaction with democracy, and less trust in key political institutions (Heath et al., 2013). Therefore I expect that Islamophobia, a particularized form of discrimination, will lead to great political alienation among Muslims.

H1: Perceptions of Islamophobia are positively associated with political alienation

Feelings of alienation from a political community and system can be associated with lower levels of political engagement, so one might expect Islamophobia to be negatively associated with political participation. However, lower satisfaction and trust can lead to non-conventional political participation - if one does not trust the institutions or people in power, direct political action is more appealing (Seligson, 1980). Moreover, discrimination can promote political participation in some circumstances (Pantoja, Ramirez, \& Segura, 2001; Shingles, 1981). Therefore I expect that Islamophobia will be associated with less non-electoral participation, but with higher turnout.

H2: Perceptions of Islamophobia are associated with a greater likelihood of nonelectoral political participation

H3: Perceptions of Islamophobia are associated with a lesser likelihood of voting 
This article was published in Ethnicities through OnlineFirst on July $12^{\text {th }} 2016$, and this is the version that should be cited. The final version can be found at:

http://etn.sagepub.com/content/early/2016/07/12/1468796816656674.full.pdf+html

The DOI is $10.1177 / 1468796816656674$.

Valence theory predicts that voters will withdraw their support from a political system that fails to deliver their preferred outcomes on key political issues (Clarke et al., 2009); disapproval for the wars in Afghanistan and Iraq were particularly high among Muslims, insofar as there was noticeable shift in vote choice at the next election (Curtice et al., 2005). Consequently many Muslims found their views unrepresented in party politics, and so I expect an increase in political alienation.

H4: Disapproval of British military involvement in Afghanistan is positively associated with political alienation.

There are conflicting expectations as to whether disagreement with a major policy will be associated with a greater or lesser likelihood of political participation. On the one hand, there is a greater incentive to participate; on the other, with all three parties in favor of the war in Afghanistan there is little reason to believe that one would be listened to, at least with regards to voting. For this reason I expect that Muslims who disagree with the war in Afghanistan will be less likely to vote. In contrast, anti-war movements in the UK have been largely protest-based. Therefore I expect those who disagree with the war in Afghanistan to be more likely to engage in non-electoral participation.

H5: Disapproval of British military involvement in Afghanistan is associated with a lesser likelihood of voting

H6: Disapproval of British military involvement in Afghanistan is associated with a greater likelihood of non-electoral political participation 
This article was published in Ethnicities through OnlineFirst on July $12^{\text {th }} 2016$, and this is the version that should be cited. The final version can be found at:

http://etn.sagepub.com/content/early/2016/07/12/1468796816656674.full.pdf+html

The DOI is $10.1177 / 1468796816656674$.

\section{Data and measures}

\section{Data}

The 2010 Ethnic Minority British Election Study is a nationally representative probability survey of the major ethnic minority groups in Britain. It was closely coordinated with the 2010 British Election Study, and includes a large number of variables on political attitudes and behavior. Areas where less than 2 percent of the residents were ethnic minorities in the 2001 Census were excluded from the sampling frame, and the response rate was between 58 percent and 66 percent. The number of Muslim respondents in EMBES is 1121, of which 638 are of Pakistani origin, 264 of Bangladeshi origin and 139 of black African origin.

\section{Dependent variables}

Political alienation can be measured in multiple ways. Here, factor analysis of a group of indicators is used to get a more comprehensive and coherent measure than any one question could provide. Factor analysis looks at covariance between different question responses to construct a measure of an underlying latent variable. The questions selected for this factor analysis were chosen as they each provide some information on political alienation. A number of different combinations were explored; these particular items were chosen because they represent a number of potential dimensions of political alienation, but also covary in a way that is consistent with a latent variable approach. I look at political efficacy, satisfaction with democracy, feeling that "politicians are only interested in the votes of black and Asian people, not their opinions", trust in politicians, interest in the 2010 general election, trust in parliament, trust in the police, feeling that opportunities for black and Asian people will remain the same regardless of which party is in power, feeling a sense of satisfaction in 
This article was published in Ethnicities through OnlineFirst on July $12^{\text {th }} 2016$, and this is the version that should be cited. The final version can be found at: http://etn.sagepub.com/content/early/2016/07/12/1468796816656674.full.pdf+html

The DOI is $10.1177 / 1468796816656674$.

voting, believing that voting is a civic duty, and thinking that no party fully represents one's views. These items each had a small number of missing values, which combined meant that 140 respondents do not have a score for the factor and are excluded from this part of the analysis.

I measure turnout using self-reported information on whether someone voted or not. ${ }^{\mathrm{iii}}$ For non-electoral participation I look at the three available measures which deal with explicitly non-partisan politics - attending a protest, signing a petition or boycotting a product or service in the past 12 months.

\section{Factor analysis}

I use three tests to determine whether the set of political alienation measures is suitable for factor analysis. Cronbach's alpha is .66 , above the .6 that is conventionally considered suitable. Bartlett's test of sphericity is significant ( $\mathrm{p}<$ .000 ), and the Kaiser-Meyer-Olkin measure of sampling adequacy is .81 - higher than .6 which is considered adequate. These tests suggest that the variables are sufficiently correlated that factor analysis is an appropriate method of analysis. I use principal factor analysis and orthogonal varimax rotation to extract the factors, and a scree test to determine the number of factors to retain. Theoretically I expect there to be one factor, measuring alienation (or its opposite). The leveling off after the first factor in a screeplot of eigenvalues supported the expectation of a one-factor solution. ${ }^{\text {iv }}$ The results reported here use only Muslim respondents to extract the factors.

Table 1 shows the factor loadings. All but two are above .3, suggesting a decent degree of communality between the different variables and the factor. The variables 
This article was published in Ethnicities through OnlineFirst on July $12^{\text {th }} 2016$, and this is the version that should be cited. The final version can be found at:

http://etn.sagepub.com/content/early/2016/07/12/1468796816656674.full.pdf+html

The DOI is $10.1177 / 1468796816656674$.

with the highest loading are trust in politics (-.73) and trust in parliament (-.65). The

lowest are feeling that opportunities for ethnic minorities remain the same regardless of who is in power (.11), interest in the general election (.28) and political efficacy (.30). Most variables are correlated in such a way that the more negative end is a higher score on the factor, so I interpret this factor as a measure of alienation i.e. a higher score indicates someone with higher alienation.

\section{Independent variables}

I measure perceptions of Islamophobia using a question that asks "which groups, if any, do you think there is prejudice against?". Responses are unprompted, and the previous question implies that the interviewer is interested in "racial prejudice nowadays". Responses that Muslims face prejudice today (36 percent of the Muslims in our sample $)^{\mathrm{v}}$ are coded as perceiving Islamophobia. This question differs slightly from asking whether Muslim respondents have themselves experienced discrimination as a result of their religion. Instead, this question measures perceptions of sociotropic discrimination, a concept that has a lot in common with the idea of "linked fate" (Dawson, 1994).

Egocentric discrimination is measured by asking whether the respondent has, in the past 5 years, "experienced discrimination or been treated unfairly by others in the UK because of [their] ethnicity, race, skin colour, language, accent, religion, age, gender, sexuality or disability?". This allows us to measure the relative incidence of discrimination among different groups, and also to differentiate between its causes. Sociotropic discrimination for other groups is measured using the same question as 
This article was published in Ethnicities through OnlineFirst on July $12^{\text {th }} 2016$, and this is the version that should be cited. The final version can be found at:

http://etn.sagepub.com/content/early/2016/07/12/1468796816656674.full.pdf+html

The DOI is $10.1177 / 1468796816656674$.

for Muslims; I use information on whether respondents thought there is discrimination

against Sikhs, Hindus and Asians in general.

EMBES asks to what extent respondents support the war in Afghanistan. I look at Afghanistan because there was no major party opposition to it. The question wording is "Please indicate whether you strongly approve, approve, disapprove, or strongly disapprove of Britain's involvement in the war against the Taliban in Afghanistan", and response categories also included "neither approve nor disapprove" and "don't know". Although it is a scale I treat this as a continuous variable, with 5 as "strongly approve" and 1 as "strongly disapprove".

I control for a number of factors known to be associated with political attitudes and participation. Immigration generation and age are both related to ethnic minority political engagement and integration (Heath, Fisher, Sanders, \& Sobolewska, 2011; Maxwell, 2010). Higher education is associated with more conventional and nonconventional political participation (Brady, Verba, \& Schlozman, 1995), and with some differences in political attitudes. I control for ethnicity, because not all Muslims in the UK have the same ethnic background, and Pakistani origin Muslims have stronger feelings of opposition to Afghanistan than other Muslim groups (Fisher, Heath, Sanders, \& Sobolewska, 2011). A lack of language fluency is generally associated with lower political participation (Heath et al., 2013). I also control for subjective importance of religion, as it may be that Muslims with a greater sense of religious identity may feel more separate from British society and politics due to increased salience of a non-mainstream identity, above and beyond perceptions of Islamophobia or disagreement with foreign policy. Social capital has a strong 
This article was published in Ethnicities through OnlineFirst on July $12^{\text {th }} 2016$, and this is the version that should be cited. The final version can be found at:

http://etn.sagepub.com/content/early/2016/07/12/1468796816656674.full.pdf+html

The DOI is $10.1177 / 1468796816656674$.

theoretical role to play in explaining both electoral and non-electoral participation. I

choose only to include associational capital as Heath et al. (2013) found this to be important. I consider the effects of both bridging social capital (membership of a voluntary organization where more than half the members are of a different ethnic group) and bonding social capital (membership of an ethnic or religious organization). Finally, there are three contextual variables included. Firstly, I include the marginality of the seat on the basis that marginal seats receive a disproportionate amount of political attention and this would be expected to increase turnout and affect political attitudes. The reference category is ultrasafe (where the margin of victory is greater than 20 percentage points), and the comparison categories are safe (margin of victory between 10 and 20 percentage points) and marginal (margin of victory less than 10 percentage point). For the same reasons I control for whether any party contacted the respondent during the election campaign. And finally I control for the percentage of Muslim residents in the constituency during the 2011 Census, as Fieldhouse and Cutts (2008a) showed the positive effect on turnout for Muslims of having religious neighbours.

\section{Methods}

For turnout I use logistic regression as the dependent variable is binary and neither event (voting or abstention) is particularly unlikely. For the three measures of nonelectoral participation however there is a risk of bias because the number of successes is extremely small compared to the number of failures - i.e. far more people did not participate than did participate in any non-electoral political activity - so these successes should be treated as rare events. This is a potential source of bias when using maximum likelihood estimation: because far more information is available 
This article was published in Ethnicities through OnlineFirst on July $12^{\text {th }} 2016$, and this is the version that should be cited. The final version can be found at:

http://etn.sagepub.com/content/early/2016/07/12/1468796816656674.full.pdf+html

The DOI is $10.1177 / 1468796816656674$.

about failures, the estimate of the successes will be biased downwards (King \& Zeng, 2001). To correct for this I use penalized maximum likelihood logistic regression, as proposed by Firth (1993).

\section{Results}

\section{Perceptions of discrimination and support for the war in Afghanistan}

Table 2 shows the percentages of ethnic minorities from different religions that report experiencing or perceiving discrimination. When we look at egocentric experiences of discrimination for any reason, there is little evidence of Islamophobia; Muslims are no more likely to report having been discriminated against for any reason than are Hindus (27 percent compared to 25 percent), and Sikhs, Christians and atheists are more likely to report experiencing discrimination than Muslims. The high percentages reporting discrimination among ethnic minority Christians and atheists (42 percent and 47 percent respectively) is explained by the greater proportion of black

Caribbeans in these religious groups, who are more likely to report experiencing discrimination than other ethnic groups. However, if we look at the reasons given for discrimination we can see that Muslims are much more likely to report that they were discriminated against because of their religion than are members of other minority religions; 49 percent of Muslims who reported an incident of discrimination said it was due to their religion as opposed to 17 percent of Sikhs and 5 percent of Hindus. This is evidence that Muslims attribute more discrimination to their religion than members of other minority religions, even if others are equally likely to report discrimination for other reasons. Accordingly, if we compare incidences of religious discrimination between Muslims and other groups, 13 percent of Muslims report 
This article was published in Ethnicities through OnlineFirst on July $12^{\text {th }} 2016$, and this is the version that should be cited. The final version can be found at:

http://etn.sagepub.com/content/early/2016/07/12/1468796816656674.full.pdf+html

The DOI is $10.1177 / 1468796816656674$.

experiencing religious discrimination as opposed to 6 percent of Sikhs and 1 percent

of Hindus.

A similar pattern emerges with sociotropic discrimination. There are no differences between Sikhs, Hindus and Muslims as to whether they think Asians face racial prejudice in Britain: 41-43 percent of each group believes this. However, when it comes to religious groups, Muslims are much more likely to say that their own religious group face racial prejudice than are either Sikhs or Hindus. 35 percent of Muslims believe that Muslims face racial prejudice, compared to 7 percent of Sikhs who believe that Sikhs do so, and 8 percent of Hindus who believe that Hindus do so. Racial discrimination is a real issue for ethnic minorities of South Asian origin, but religious discrimination is markedly more salient for Muslims than for Hindus or Sikhs. ${ }^{\text {vi }}$

We can also see from the same table that Muslims are far less supportive of British involvement in the war in Afghanistan than other ethnic minorities; only 8 percent of Muslims approve or strongly approve of "Britain's involvement in the war against the Taliban in Afghanistan", compared to 26 percent of Hindus and 26 percent of Sikhs.

\section{Political attitudes}

Table 3 shows the results of an OLS model of political alienation. The coefficient for perceiving Islamophobia is positive, suggesting that Muslims who perceive Islamophobia are more politically alienated than Muslims who do not. This confirms hypothesis 1. Approval of the war in Afghanistan is associated with less alienation. Therefore Muslims who disapproved more of the war in Afghanistan are on average 
This article was published in Ethnicities through OnlineFirst on July $12^{\text {th }} 2016$, and this is the version that should be cited. The final version can be found at:

http://etn.sagepub.com/content/early/2016/07/12/1468796816656674.full.pdf+html

The DOI is $10.1177 / 1468796816656674$.

more politically alienated than Muslims who disapprove less, or approve. This

confirms hypothesis 4 .

The dependent variable has an arbitrary value, so it is difficult to interpret the size of these effects. However, we can compare its size to those of another important predictor, also binary. The coefficient for immigrant generation (2nd and later generations as compared to the 1st) is .40 . The coefficient for perceiving Islamophobia is half this size at .23 , and for experiencing religious discrimination it is two-thirds of the size at .29. Taking confidence intervals into account we cannot discount the possibility that the effect sizes are the same. The other significant binary predictor in the model, not being fluent in English, also has a coefficient of -.26 (with a different sign). Both immigrant generation and language fluency are generally taken to be substantively important predictors, so there is a case for arguing that perceptions of religious prejudice play an equally important role in explaining some political attitudes among Muslims.

The model has an adjusted r-squared value of .14, suggesting that it does a reasonable job of explaining some of the variance in the scale - but there is much left unexplained. Further attempts to increase the amount of variance explained resulted in a long list of mostly insignificant variables, and not much improvement in the adjusted r-squared. The total number of observations is 843 , reduced from a total sample of 1121 Muslims in EMBES. This is due to missing values; 140 of these are due to missing values in the items used in the factor analysis, and 189 of these are those who answered "don't know" to the question on the war in Afghanistan (there is 
This article was published in Ethnicities through OnlineFirst on July $12^{\text {th }} 2016$, and this is the version that should be cited. The final version can be found at:

http://etn.sagepub.com/content/early/2016/07/12/1468796816656674.full.pdf+html

The DOI is $10.1177 / 1468796816656674$.

some overlap). ${ }^{\text {vii }}$ Other choices in the coding of missing responses meant that a

number of respondents are excluded from the final analysis.

\section{Political participation}

Table 4 reports the results of six models of different types of political participation.

The first three models presented are logistic regression models of turnout estimated using maximum likelihood; the other models reported use penalized maximum likelihood to reduce bias in the estimates due to the outcomes being rare events.

Firstly, turnout. In the first model, neither sociotropic discrimination nor egocentric discrimination are significant, and the same is true for disapproval of the war in Afghanistan. Bearing in mind potential collinearity between the two measures of discrimination, I separate them out. When considered separately, both sociotropic and egocentric discrimination have negative effects on turnout - in line with hypothesis 3 - although egocentric discrimination is just outside significance $(p=.05)$. However, support for the war in Afghanistan is unrelated to turnout, against hypothesis 6.

Predicted probabilities of the effect of both types of discrimination are taken from the models that consider them in isolation. These models predict that a Muslim person who reported that Muslims face racial prejudice has a probability of voting of .53, compared to .61 for someone who did not report that. Similarly, a Muslim person who reported experiencing religious discrimination has a predicted probability of voting of .50 , compared to .59 . These predicted probabilities are calculated for a reference person of median age (33), who was born outside the UK, is fluent in English, whose religion is very important to them (the median response), does not belong to an ethnic or religious association, or one where greater than 50 percent of the members are of a 
This article was published in Ethnicities through OnlineFirst on July $12^{\text {th }} 2016$, and this is the version that should be cited. The final version can be found at:

http://etn.sagepub.com/content/early/2016/07/12/1468796816656674.full.pdf+html

The DOI is $10.1177 / 1468796816656674$.

different ethnic group, lives in a safe seat where 21 percent of the residents are

Muslim (the median), and who has been contacted by a party.

Moving on, what can we say about non-electoral participation? Egocentric discrimination is positively associated with a greater likelihood of all three nonelectoral political activities - attending a protest or demonstration (using a reference person as in the previous paragraph except not having been contact by a party, the predicted probability without experiencing religious discrimination is .08 , compared to .12 with), signing a petition (predicted probability of .29 without, compared to .59 with), or boycotting a product or service (predicted probability of .06 without, compared to .15 with). Perceptions of Islamophobia are positively associated with two of these - petition signing ( .29 without, compared to .44 with) and boycotting a product or service (predicted probability of .06 without, compared to .11 with). This confirms hypothesis 2. Approval of the war in Afghanistan is negatively associated with boycotting and petitions signing i.e. those who disapprove were more likely to take part in these activities. The predicted probability of our reference person taking part in a boycott if they strongly disapprove is .09 , but .05 if they neither approve nor disapprove. Similarly, the predicted probability of signing a petition is .35 if they strongly disapprove of the war, compared to .25 if they neither approve nor disapprove. Attitudes to the war in Afghanistan are unrelated to protest attendance.

Another way into the subject of political participation is to concentrate only on those who participate in some way. Table 5 presents the results of a multinomial regression analysis comparing different kinds of participation; the base category are people who both voted and engaged in at least one form of non-electoral participation (162), as 
This article was published in Ethnicities through OnlineFirst on July $12^{\text {th }} 2016$, and this is the version that should be cited. The final version can be found at:

http://etn.sagepub.com/content/early/2016/07/12/1468796816656674.full.pdf+html

The DOI is $10.1177 / 1468796816656674$.

compared to those who only voted (516), or those who only engaged in non-electoral

participation (162). 364 Muslim respondents did not engage in either. Approval of the war in Afghanistan is not significantly related to either type of participation, whilst egocentric discrimination is positively related to non-electoral participation (as compared to both types of participation), and sociotropic discrimination is negatively related to only voting. Given that the comparison here is between voting alone, and voting combined with non-electoral participation, I interpret these results as further evidence that discrimination can be driver of non-electoral participation - among those who did participate in at least one way, discrimination (egocentric or sociotropic) is associated with a greater likelihood of non-electoral participation, even in combination with voting.

\section{Discussion and Conclusions}

The main findings of this study are threefold. Firstly, Muslims do not report experiencing more discrimination than Sikhs and Hindus - but they are more likely to attribute it to their religion. Secondly, that personal experiences and group-level perceiptions of discrimination are associated with political alienation, a greater likelihood of engaging in non-electoral participation, and a lesser likelihood of voting. Thirdly, that disapproval of the war in Afghanistan among Muslims in the UK is similarly associated with political alienation, and a greater likelihood of engaging in non-electoral participation.

This analysis uses cross-sectional data and therefore cannot demonstrate causality; with hypothesis testing we can only say that these results are consistent or inconsistent with certain causal stories. Although there are strong theoretical reasons to interpret these findings in a causal manner, it is also plausible that there is some 
This article was published in Ethnicities through OnlineFirst on July $12^{\text {th }} 2016$, and this is the version that should be cited. The final version can be found at:

http://etn.sagepub.com/content/early/2016/07/12/1468796816656674.full.pdf+html

The DOI is $10.1177 / 1468796816656674$.

reverse causation or a confounding influence at work, i.e. that those who are more

politically alienated and oriented to protest politics are more likely to perceive

discrimination and object more strongly to British military action in Muslim

countries. Nevertheless, even if the causal direction is the opposite to that outlined

here, it is still worth knowing how alienation and political participation correlate with approval of the war in Afghanistan and experiences of discrimination.

Muslims do not report more personal experiences of discrimination than other South Asian origin groups i.e. Sikhs and Hindus. Nor are they more inclined to think that Asians in Britain face racial prejudice. ${ }^{\text {viii }}$ However, religious discrimination is much more salient for Muslims than for other minority religions; of those who report being discriminated against, 49 percent of Muslims attributed it to their religion compared to 17 percent of Sikhs and 5 percent of Hindus. Moreover, far more Muslims say that people from their religion face prejudice than do Sikhs or Hindus. This complements work arguing that religion, rather than ethnicity, is becoming a more salient identity for many Muslims (Michael, 2011; Voas \& Fleischmann, 2012).

These results are consistent with the idea that sociotropic discrimination leads to political alienation, and is associated with a rejection of voting or with more nonelectoral political participation. However, when looking only at people who engaged in at least one form of political participation, it becomes clear that for many people, non-electoral participation is a complement to voting. These results suggest that Muslims with experiences of egocentric and sociotropic discrimination might see mainstream political institutions and actors as insufficient, leading some to disengage by not voting, but others express this dissatisfaction through more direct methods. 
This article was published in Ethnicities through OnlineFirst on July $12^{\text {th }} 2016$, and this is the version that should be cited. The final version can be found at:

http://etn.sagepub.com/content/early/2016/07/12/1468796816656674.full.pdf+html

The DOI is $10.1177 / 1468796816656674$.

Turning now to the legacy of Afghanistan on Muslim political attitudes and participation, there is evidence that dissatisfaction with these engagements may have had an impact almost a decade after troops were first sent to Afghanistan (at the time of the fieldwork in 2010). Muslims who disagreed with Britain's involvement in Afghanistan were more politically alienated, and more likely to engage in two forms of non-electoral politics. This contrasts with electoral research which suggested that the effect had disappeared by the 2010 election (Curtice, Fisher, \& Ford, 2010). It is interesting that feelings about Afghanistan were unrelated to the likelihood of attending a protest, given the importance of protest to the anti-war movement. Although the study did not ask about attitudes towards the war in Iraq, we can speculate that the results about attitudes towards the war in Afghanistan also apply to the war in Iraq. Afghanistan was a less unpopular war, and it seems unlikely that Muslims who strongly disapproved of intervention in Afghanistan were simultaneously strongly approving of military action in Iraq.

Some context is appropriate as regards the absolute levels of political alienation among Muslims; when it comes to political efficacy and satisfaction with democracy, Muslims are more satisfied than the white British. 37 percent of Muslims feel that they have no political influence, compared to 40 percent of the white British. Similarly, 21 percent of Muslims say they are very or a little dissatisfied with the way democracy works in this country, compared to 35 percent of the white British. Muslims who find themselves alienated from politics are in the company of a substantial proportion of the white British population as well. 
This article was published in Ethnicities through OnlineFirst on July $12^{\text {th }} 2016$, and this is the version that should be cited. The final version can be found at:

http://etn.sagepub.com/content/early/2016/07/12/1468796816656674.full.pdf+html

The DOI is $10.1177 / 1468796816656674$.

This paper has focused on Muslims in Britain, but there are theoretical implications

beyond this group. Given existing scholarship, there is a strong case to be made that the result that discrimination is associated with politically alienated attitudes is one that generalizable to other ethnic minority groups in Britain and Europe (Heath et al., 2013; Maxwell, 2009). There are similarities between the story where Islamophobia is associated with non-electoral politics and the role of protest politics in African American, Latino and Native American enfranchisement and political mobilisation. Similarly, the importance of sociotropic discrimination for many of the dependent variables even when egocentric discrimination suggests that the concept of linked fate is applicable and important outside the American context and when applied to other political behaviours and attitudes than vote choice.

Future research on Muslim political behaviour and attitudes in the UK should monitor to what extent political alienation persists among this group. Although British combat forces have now left Afghanistan, there have been recurring debates about military intervention in both Libya and Syria. Muslim commentators have often expressed opposition to these interventions. Meanwhile advocacy organisations have reported an increase in harassment and violence towards Muslims in the UK in the wake of Islamist terrorist attacks in Paris and elsewhere. It will be important to consider how these factors might influence the 2020 UK general election. Insofar as representation of the political interests of Muslims voters is concerned, it is an interesting question as to how effective initiatives like the Muslim Manifesto were in increasing substantive representation at the 2015 general election and beyond. It was notable that, in contrast to 2010, most parties dedicated a section in their manifesto to ethnic and religious equality, with some having separate manifestoes targeting to target different groups. 
This article was published in Ethnicities through OnlineFirst on July $12^{\text {th }} 2016$, and this is the version that should be cited. The final version can be found at:

http://etn.sagepub.com/content/early/2016/07/12/1468796816656674.full.pdf+html

The DOI is $10.1177 / 1468796816656674$.

In summary, this paper presents evidence that Islamophobia is associated with political alienation among Muslims, a greater likelihood of engaging in non-electoral politics, and a lesser likelihood of voting. Disapproval of the war in Afghanistan is likewise associated with greater political alienation among Muslims, and a greater likelihood of some forms of non-electoral political engagement. The association between perceptions of Islamophobia and political alienation may be taken as a warning that the largest religious minority in Britain is at risk of political exclusion if anti-Muslim sentiment remains commonplace. 
This article was published in Ethnicities through OnlineFirst on July $12^{\text {th }} 2016$, and this is the version that should be cited. The final version can be found at:

http://etn.sagepub.com/content/early/2016/07/12/1468796816656674.full.pdf+html

The DOI is $10.1177 / 1468796816656674$.

Table 1: factor loadings

Variable

Factor loadings

Uniqueness

Efficacy

0.28

0.91

Satisfaction with democracy

0.55

0.70

Only interested in votes

$-0.35$

0.73

0.87

Trust politicians

$-0.28$

0.47

nterest in GE

0.65

0.92

Trust parliament

0.56

0.57

Trust police

$-0.11$

0.69

Eame

regardless of party

Feel sense of satisfaction when vote

$0.36-0.86$
$-0.37-0.86$

Voting is a civic duty

0.37

0.86

No party represents r's views best

$-0.42$

0.86

Data: Ethnic Minority British Election Study 2010

0.82

Muslim respondents only

Table 2: experiences and support for the war in Afghanistan among EMBES respondents

\begin{tabular}{llllll} 
& Christian & Hindu & Muslim & Sikh & None \\
\hline Egocentric discrimination for any reason & $42 \%$ & $25 \%$ & $27 \%$ & $37 \%$ & $47 \%$ \\
$\quad$ Of which attributed to respondent's religion & $9 \%$ & $5 \%$ & $49 \%$ & $17 \%$ & $4 \%$ \\
Experienced rel. discrimination & $4 \%$ & $1 \%$ & $13 \%$ & $6 \%$ & $2 \%$ \\
Sociotropic discrimination &. & $8 \%$ & $35 \%$ & $7 \%$ &. \\
Support war in Afghanistan & $22 \%$ & $26 \%$ & $8 \%$ & $26 \%$ & $17 \%$ \\
\hline
\end{tabular}

Base: all EMBES respondents 
This article was published in Ethnicities through OnlineFirst on July $12^{\text {th }} 2016$, and this is the version that should be cited. The final version can be found at:

http://etn.sagepub.com/content/early/2016/07/12/1468796816656674.full.pdf+html

The DOI is $10.1177 / 1468796816656674$.

Table 3: OLS regression model of positive system affect/political alienation System affect

\begin{tabular}{lll} 
& Coefficient & SE \\
\hline Sociotropic Islamophobia & $-0.23^{* * *}$ & 0.06 \\
Egocentric Islamophobia & $-0.29^{* * *}$ & 0.08 \\
Support for Afghan war & $0.11^{* * *}$ & 0.03 \\
1st gen (ref.) & & \\
2nd and later gen & $-0.40^{* * *}$ & 0.07 \\
Age & 0.00 & 0.00 \\
Pakistani (ref.) & & \\
Indian & 0.16 & 0.11 \\
Bangladeshi & -0.01 & 0.07 \\
Black Caribbean/African & -0.12 & 0.09 \\
Not fluent in English & $0.26 * * *$ & 0.07 \\
Importance of religion & -0.01 & 0.04 \\
Bridging assoc. capital & 0.08 & 0.09 \\
Bonding assoc. capital & 0.08 & 0.06 \\
GCSE or equivalent (ref.) & & \\
A level or equivalent & 0.02 & 0.07 \\
Degree or higher & 0.06 & 0.08 \\
Ultrasafe seat (ref.) & & \\
Safe seat & 0.02 & 0.08 \\
Marginal seat & 0.04 & 0.07 \\
\% Muslim in constituency & -0.001 & 0.002 \\
Contacted by any party & 0.03 & 0.06 \\
Constant & 0.01 & 0.26 \\
\hline N & 843 & \\
Adjusted R2 & 0.14 & \\
\hline \% $0.05, *<0.01, p<0.001$ & & \\
\hline
\end{tabular}

$* p<0.05, * * p<0.01, p<0.001$

Data: Ethnic Minority British Election Study 2010

Muslim respondents only 
This article was published in Ethnicities through OnlineFirst on July $12^{\text {th }} 2016$, and this is the version that should be cited. The final version can be found at: http://etn.sagepub.com/content/early/2016/07/12/1468796816656674.full.pdf+html

The DOI is $10.1177 / 1468796816656674$.

Table 4: logistic regression models of political participation

\begin{tabular}{|c|c|c|c|c|c|c|c|c|c|c|c|c|}
\hline & \multicolumn{2}{|c|}{ Turnout } & \multicolumn{2}{|c|}{ Turnout } & \multicolumn{2}{|c|}{ Turnout } & \multicolumn{2}{|c|}{ Protest } & \multicolumn{2}{|c|}{ Petition } & \multicolumn{2}{|c|}{ Boycott } \\
\hline & Coef. & SE & Coef. & SE & Coef. & SE & Coef. & SE & Coef. & SE & Coef. & SE \\
\hline \multicolumn{13}{|l|}{ Sociotropic } \\
\hline Islamophobia & $-0.31 *$ & 0.15 & & & -0.27 & 0.15 & 0.42 & 0.26 & $0.39 *$ & 0.19 & $0.56 *$ & 0.25 \\
\hline \multicolumn{13}{|l|}{ Egocentric } \\
\hline Islamophobia & & & -0.40 & 0.20 & -0.33 & 0.21 & $0.81 * *$ & 0.28 & $0.70 * *$ & 0.23 & $0.87 * *$ & 0.27 \\
\hline \multicolumn{13}{|l|}{ Support for Afghan } \\
\hline \multicolumn{13}{|l|}{ 1st gen (ref.) } \\
\hline 2nd and later gen & 0.23 & 0.18 & 0.21 & 0.18 & 0.24 & 0.18 & 0.39 & 0.29 & 0.19 & 0.21 & 0.3 & 0.28 \\
\hline Age & $0.02 *$ & 0.01 & $0.01 *$ & 0.01 & $0.02 *$ & 0.01 & -0.01 & 0.01 & 0.01 & 0.01 & -0.01 & 0.01 \\
\hline \multicolumn{13}{|l|}{ Pakistani (ref.) } \\
\hline Indian & 0.14 & 0.29 & 0.15 & 0.29 & 0.15 & 0.29 & 0.26 & 0.48 & -0.03 & 0.34 & 0.32 & 0.41 \\
\hline Bangladeshi & 0.33 & 0.19 & 0.31 & 0.19 & 0.32 & 0.19 & 0.35 & 0.31 & -0.04 & 0.23 & -0.11 & 0.32 \\
\hline \multicolumn{13}{|l|}{ Black } \\
\hline Caribbean/African & -0.40 & 0.22 & -0.41 & 0.22 & -0.40 & 0.22 & -0.25 & 0.45 & $-0.70 *$ & 0.33 & -0.48 & 0.43 \\
\hline Not fluent in English & 0.20 & 0.18 & 0.18 & 0.18 & 0.19 & 0.18 & -0.57 & 0.39 & $-0.96 * * *$ & 0.27 & $-0.84 *$ & 0.4 \\
\hline Importance of religion & 0.03 & 0.10 & 0.05 & 0.10 & 0.04 & 0.10 & -0.07 & 0.18 & 0.17 & 0.14 & -0.22 & 0.17 \\
\hline \multicolumn{13}{|l|}{ Bridging assoc. } \\
\hline capital & 0.02 & 0.22 & 0.00 & 0.22 & 0.03 & 0.22 & 0.44 & 0.3 & 0.43 & 0.24 & -0.13 & 0.32 \\
\hline Bonding assoc. capital & 0.23 & 0.16 & 0.26 & 0.16 & 0.25 & 0.16 & $1.23 * * *$ & 0.25 & $0.80 * * *$ & 0.19 & $1.01 * * *$ & 0.25 \\
\hline \multicolumn{13}{|l|}{$\begin{array}{l}\text { GCSE or equivalent } \\
\text { (ref.) }\end{array}$} \\
\hline A level or equivalent & 0.10 & 0.18 & 0.05 & 0.17 & 0.09 & 0.18 & 0.3 & 0.31 & 0.34 & 0.23 & 0.36 & 0.33 \\
\hline Degree or higher & 0.18 & 0.20 & 0.15 & 0.19 & 0.18 & 0.20 & -0.06 & 0.36 & 0.21 & 0.25 & $0.91 * *$ & 0.34 \\
\hline \multicolumn{13}{|l|}{ Ultrasafe seat (ref.) } \\
\hline Safe seat & $-0.42 *$ & 0.20 & $-0.42 *$ & 0.20 & $-0.41 *$ & 0.20 & 0.32 & 0.34 & 0.43 & 0.25 & 0.03 & 0.35 \\
\hline Marginal seat & $-0.41 *$ & 0.17 & $-0.42 *$ & 0.17 & $-0.42 *$ & 0.17 & 0.22 & 0.3 & 0.05 & 0.22 & 0.33 & 0.29 \\
\hline$\%$ Muslim & -0.01 & 0.01 & -0.01 & 0.01 & -0.01 & 0.01 & 0 & 0.01 & $-0.01 *$ & 0.01 & 0 & 0.01 \\
\hline Contacted by party & $0.46^{* *}$ & 0.15 & $0.46^{* *}$ & 0.15 & $0.47 * *$ & 0.15 & 0.03 & 0.26 & 0.34 & 0.19 & -0.04 & 0.25 \\
\hline Constant & -0.15 & 0.61 & -0.16 & 0.61 & -0.12 & 0.61 & $-2.77 *$ & 1.14 & $-2.41 * *$ & 0.83 & -1.02 & 1.1 \\
\hline $\mathrm{N}$ & 906 & & 906 & & 906 & & 904 & & 903 & & 903 & \\
\hline
\end{tabular}

* $p<0.05, * * p<0.01, p<0.001$

Data: Ethnic Minority British Election Study 2010

Muslim respondents only 
This article was published in Ethnicities through OnlineFirst on July $12^{\text {th }} 2016$, and this is the version that should be cited. The final version can be found at:

http://etn.sagepub.com/content/early/2016/07/12/1468796816656674.full.pdf+htm/

The DOI is $10.1177 / 1468796816656674$.

Table 5: multinomial logistic regression models of types of turnout restricted to those who engage in at least one form of political participation.

The reference category is engaging in both non-electoral and electoral participation.

\begin{tabular}{|c|c|c|c|c|}
\hline & \multicolumn{2}{|l|}{ Voting only } & \multicolumn{2}{|c|}{ Non-electoral only } \\
\hline & Coefficient & SE & Coefficient & SE \\
\hline Sociotropic Islamophobia & $-0.60 * *$ & 0.23 & 0.37 & 0.30 \\
\hline Egocentric Islamophobia & -0.44 & 0.31 & $0.78 *$ & 0.34 \\
\hline $\begin{array}{l}\text { Support for Afghan war } \\
\text { 1st gen (ref.) }\end{array}$ & $0.26 *$ & 0.11 & -0.14 & 0.16 \\
\hline 2nd and later gen & -0.39 & 0.27 & -0.57 & 0.35 \\
\hline Age & -0.02 & 0.01 & $-0.04 *$ & 0.01 \\
\hline \multicolumn{5}{|l|}{ Pakistani (ref.) } \\
\hline Indian & -0.16 & 0.39 & -0.90 & 0.68 \\
\hline Bangladeshi & 0.25 & 0.28 & 0.08 & 0.38 \\
\hline Black Caribbean/African & $1.00^{*}$ & 0.46 & 0.78 & 0.55 \\
\hline Not fluent in English & $0.95 * *$ & 0.30 & -0.25 & 0.46 \\
\hline Importance of religion & -0.20 & 0.16 & -0.04 & 0.23 \\
\hline Bridging assoc. capital & -0.55 & 0.31 & -0.14 & 0.37 \\
\hline $\begin{array}{l}\text { Bonding assoc. capital } \\
\text { GCSE or equivalent (ref.) }\end{array}$ & $-1.11 * * *$ & 0.23 & -0.18 & 0.30 \\
\hline A level or equivalent & $-0.85 * *$ & 0.28 & $-0.93 *$ & 0.38 \\
\hline Degree or higher & $-0.75^{*}$ & 0.30 & $-1.12 * *$ & 0.41 \\
\hline \multicolumn{5}{|l|}{ Ultrasafe seat (ref.) } \\
\hline Safe seat & -0.25 & 0.30 & $0.99 *$ & 0.41 \\
\hline Marginal seat & 0.17 & 0.26 & $1.00 * *$ & 0.37 \\
\hline$\%$ Muslim in constituency & 0.004 & 0.01 & 0.01 & 0.01 \\
\hline Contacted by any party & -0.26 & 0.22 & -0.44 & 0.30 \\
\hline Constant & $3.11 * *$ & 1.00 & 1.14 & 1.41 \\
\hline $\mathrm{N}$ & 629 & & 629 & \\
\hline
\end{tabular}

Data: Ethnic Minority British Election Study 2010

Muslim respondents only 
This article was published in Ethnicities through OnlineFirst on July $12^{\text {th }} 2016$, and this is the version that should be cited. The final version can be found at:

http://etn.sagepub.com/content/early/2016/07/12/1468796816656674.full.pdf+html

The DOI is $10.1177 / 1468796816656674$.

\section{References}

Anwar, M. (1990). Muslims in Britain, some recent developments. Journal Institute of Muslim Minority Affairs.

Brady, H. E., Verba, S., \& Schlozman, K. L. (1995). Beyond SES: A resource model of political participation. American Political Science Review, 89(2), 271-294.

Citrin, J., Mcclosky, H., Shanks, J. M., \& Sniderman, P. M. (1975). Personal and Political Sources of Political Alienation. British Journal of Political Science, 5(1), $1-31$.

Clarke, H. D., Sanders, D., Stewart, M. C., \& Whiteley, P. F. (2009). Performance Politics and the British Voter. Cambridge University Press.

Curtice, J., Fisher, S. D., \& Ford, R. (2010). Appendix 1: An analysis of the results. In The British General Election of 2010. Basingstoke: Palgrave Macmillan.

Curtice, J., Fisher, S. D., \& Steed, M. (2005). Appendix 2: the results analysed. In The General Election of 2005. Basingstoke: Palgrave Macmillan.

Dawson, M. C. (1994). Behind the Mule-Race and Class in African-American Politics. Princeton : Princeton University Press.

Fieldhouse, E., \& Cutts, D. (2008a). Diversity, density and turnout: The effect of neighbourhood ethno-religious composition on voter turnout in Britain. Political Geography, 27(5), 530-548.

Fieldhouse, E., \& Cutts, D. (2008b). Mobilisation or marginalisation? Neighbourhood effects on Muslim electoral registration in Britain in 2001. Political Studies, 56(2), 333-354.

Fieldhouse, E., Cutts, D., \& Russell, A. (2006). Neither North nor South: The

Liberal Democrat Performance in the 2005 General Election. Journal of Elections, Public Opinion \& Parties, 16(1), 77-92.

Finifter, A. W. (1970). Dimensions of Political Alienation. American Political Science Review, 64(2), 389-410.

Firth, D. (1993). Bias reduction of maximum likelihood estimates. Biometrika, 80(1), 27-38.

Fisher, S. D., Heath, A., Sanders, D., \& Sobolewska, M. (2011). Ethnicity, religion and support for the war in Afghanistan. Presented at the Elections, Public Opinion and Parties Conference.

Gale, R. (2005). Representing the city: mosques and the planning process in Birmingham. Journal of Ethnic and Migration Studies, 31(6), 1161-1179.

Gamson, W. A. (1968). Power and discontent. Homewood III: Dorsey Press.

Heath, A., Fisher, S. D., Rosenblatt, G., Sanders, D., \& Sobolewska, M. (2013). The Political Integration of Ethnic Minorities in Britain. Oxford University Press.

Heath, A., Fisher, S. D., Sanders, D., \& Sobolewska, M. (2011). Ethnic Heterogeneity in the Social Bases of Voting at the 2010 British General Election. Journal of Elections, Public Opinion \& Parties, 21(3), 255-277.

Hooghe, M., \& Marien, S. (2012). A Comparative Analysis of the Relation Between Political Trust and Forms of Political Participation in Europe. European Societies, 15(1), 131-152.

Jamal, A. (2005). The Political Participation and Engagement of Muslim Americans. American Politics Research, 33(4), 521-544.

Just, A., \& Anderson, C. J. (2012). Immigrants, Citizenship and Political Action in Europe. British Journal of Political Science.

Kaufmann, K. M. (2003). Cracks in the rainbow: Group commonality as a basis for Latino and African-American political coalitions. Political Research Quarterly, $56,199-210$. 
This article was published in Ethnicities through OnlineFirst on July $12^{\text {th }} 2016$, and this is the version that should be cited. The final version can be found at:

http://etn.sagepub.com/content/early/2016/07/12/1468796816656674.full.pdf+html

The DOI is $10.1177 / 1468796816656674$.

Khan, O. (2005). Runnymede Trust Quarterly Bulletin (No. 342) (pp. 1-4).

King, G., \& Zeng, L. (2001). Logistic Regression in Rare Events Data. Political Analysis, 9(2), 137-163.

Maxwell, R. (2009). Caribbean and South Asian identification with British society: the importance of perceived discrimination. Ethnic and Racial Studies, 32(8), 1449-1469.

Maxwell, R. (2010). Evaluating Migrant Integration: Political Attitudes Across Generations in Europe. International Migration Review, 44(1), 25-52.

Michael, L. (2011). Islam as Rebellion and Conformity: How Young British Pakistani Muslims in the UK Negotiate Space for and against Radical Ideologies. Religion, State and Society, 39(2-3), 209-227.

Modood, T. (2005). Multicultural politics: Racism, ethnicity, and Muslims in Britain.

Norris, P. (1999). Critical Citizens: Global Support for Democratic Government: Global Support for Democratic Government. Oxford University Press.

Pantoja, A. D., Ramirez, R., \& Segura, G. M. (2001). Citizens by Choice, Voters by Necessity: Patterns in Political Mobilization by Naturalized Latinos. Political Research Quarterly, 54(4), 729-750.

Peace, T. (2013). All I'm Asking, Is For a Little Respect: Assessing the Performance of Britain's Most Successful Radical Left Party. Parliamentary Affairs, 66(2), 405-424.

Peace, T. (2015). British Muslims and the anti-war movement. In Muslims and Political Participation in Britain (pp. 124-138). Routledge.

Poynting, S., \& Mason, V. (2007). The resistible rise of Islamophobia Anti-Muslim racism in the UK and Australia before 11 September 2001. Journal of Social Issues, 43(1), 61-86.

Sanchez, G. R., \& Masuoka, N. (2010). Brown-Utility Heuristic? The Presence and Contributing Factors of Latino Linked Fate. Hispanic Journal of Behavioral Sciences, 32(4), 519-531.

Seligson, M. A. (1980). Trust, Efficacy and Modes of Political Participation: A Study of Costa Rican Peasants. British Journal of Political Science, 10(1), 75-98.

Shingles, R. D. (1981). Black consciousness and political participation: The missing link. The American Political Science Review, 75(1), 76-91.

Sobolewska, M., Fisher, S. D., Heath, A. F., \& Sanders, D. (2015). Understanding the effects of religious attendance on political participation among ethnic minorities of different religions. European Journal of Political Research, 54, 271-287.

Voas, D., \& Fleischmann, F. (2012). Islam Moves West: Religious Change in the First and Second Generations. Annual Review of Sociology, 38(1), 525-545.

Wilson, J. M. (2012). How are we doing? Group-based economic assessments and African American political behavior. Electoral Studies, 31(3), 550-561.

Woolf, M., \& Usborne, D. (2001, October 9). Air Strikes On Afghanistan: Peace Lobby: Anti-War Groups Pledge To Protest Across Britain While Bombings Continue. The Independent. London.

\footnotetext{
${ }^{\mathrm{i}}$ This paper focuses on Afghanistan, but it is difficult to separate this from Iraq in the context of the 2005 UK general election.

ii The 2011 Census estimated that Muslims were at least $20 \%$ or more of the population in 26 parliamentary constituencies.
} 
This article was published in Ethnicities through OnlineFirst on July $12^{\text {th }} 2016$, and this is the version that should be cited. The final version can be found at: http://etn.sagepub.com/content/early/2016/07/12/1468796816656674.full.pdf+html The DOI is $10.1177 / 1468796816656674$.

iii Although turnout validated with a linked electoral register was included in the study, it is missing for a high number of cases. The imputed data that is available is unreliable as respondents who did not consent to have their responses linked to the electoral register are not missing at random.

${ }^{\text {iv }}$ The eigenvalue of the first factor is 2.33 , of the second is 0.35 , and the third is 0.25 .

${ }^{\mathrm{v}}$ Many non-Muslims also said that Muslims face prejudice although the proportion is slightly smaller - 32 per cent of non-Muslims compared to 36 per cent of Muslims. The difference is statistically significant.

${ }^{\mathrm{vi}}$ Sikhs and Hindus are the most appropriate comparison groups for Muslims in this context, because they are minority religions in the UK, whose adherents are mostly ethnic minorities. Nevertheless, whilst Sikhs and Hindus in the UK are almost exclusively of South Asian origin, there are 139 Muslim respondents in the sample of black African origin.

${ }^{\text {vii }}$ Excluding these responses reduces the effective sample size, so the other option explored was to include these respondents somehow. Fisher et al. (2011) suggest that "don't know" responses to this question (particularly among Bangladeshis) might indicate disapproval due to social desirability bias, so I coded these responses as disapproval. Ultimately the results were the same regardless of whether these respondents were included or not, so the decision was made to exclude them on the basis that the decision to ascribe views to these respondents without having observed them was less defensible than dropping them.

viii The fieldwork for this study was undertaken in 2010, so it is unclear to what extent this might have changed since then. 